Biol. Stud. 2021; 15(4): 87-104 • DOI: https://doi.org/10.30970/sbi.1504.671

www.http://publications.Inu.edu.ua/journals/index.php/biology

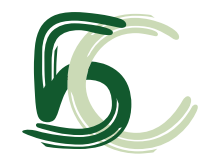

UDC: [612.112:616.379-008.64]:616-085.831

\title{
EFFECT OF PHOTOBIOMODULATION THERAPY ON THE REGULATION OF GLUCOSE UPTAKE BY LYMPHOCYTES IN DIABETES MELLITUS (REVIEW)
}

\author{
A. O. Maslakova®, M. Ya. Liuta $₫$, N. O. Sybirna \\ Ivan Franko National University of Lviv, 4 Hrushevskyi St., Lviv 79005, Ukraine
}

Maslakova, A. O., Liuta, M. Ya., \& Sybirna, N. O. (2021). Effect of photobiomodulation therapy on the regulation of glucose uptake by lymphocytes in diabetes mellitus (Review). Studia Biologica, 15(4): 87-104 • DOI: https://doi.org/10.30970/sbi.1504.671

For most cells, including lymphocytes, glucose is a primary energy source, and, therefore, it is vital to understand the regulatory mechanisms that control the work of glucose transporters. Lymphocytes are pivotal for mediation of immune and inflammatory responses. A feature of lymphocytes is increasing glucose utilization during activation of the immune function, which is strongly dependent on glucose uptake. Some studies show that elevated glucose concentration in diabetes mellitus affects lymphocytes' glucose transporters expression, which correlates with impaired immune functions and may become one of the predisposing factors of contracting infectious diseases. Recent studies have focused on glucose transporters as therapeutic targets for a variety of diseases, including diabetes mellitus. This review demonstrates the effect of photobiomodulation therapy on glucose uptake by $\mathrm{Na}^{+}$-coupled glucose carrier SGLT1 and facilitated diffusion glucose carriers of the GLUT family (GLUT1, GLUT3, GLUT4) in normal and diabetic lymphocytes.

Keywords: GLUT, SGLT1, photobiomodulation, lymphocytes, diabetes mellitus
ABBREVIATION LIST
AC - Adenylate cyclase;
Akt - Protein kinase B;
AMPK - AMP-activated protein kinase;
ATP $\quad-$ Adenosine triphosphate;
CAMKK $\beta-\mathrm{Ca}^{+2} /$ calmodulin-dependent kinase kinase $\beta$;
CAMP - Cyclic adenosine monophosphate;
CREB - CAMP response element-binding protein;

() 2021 A. O. Maslakova, M. Ya. Liuta, \& N. O. Sybirna. Published by the Ivan Franko National University of Lviv on behalf of Біологічн Студії / Studia Biologica. This is an Open Access article distributed under the terms of the Creative Commons Attribution 4.0 License which permits unrestricted reuse, distribution, and reproduction in any medium, provided the original work is properly cited.

ISSN 1996-4536 (print) • ISSN 2311-0783 (on-line) • Біологічні Студії / Studia Biologica • 2021 • Том 15 / № 4 • C. 84-104 


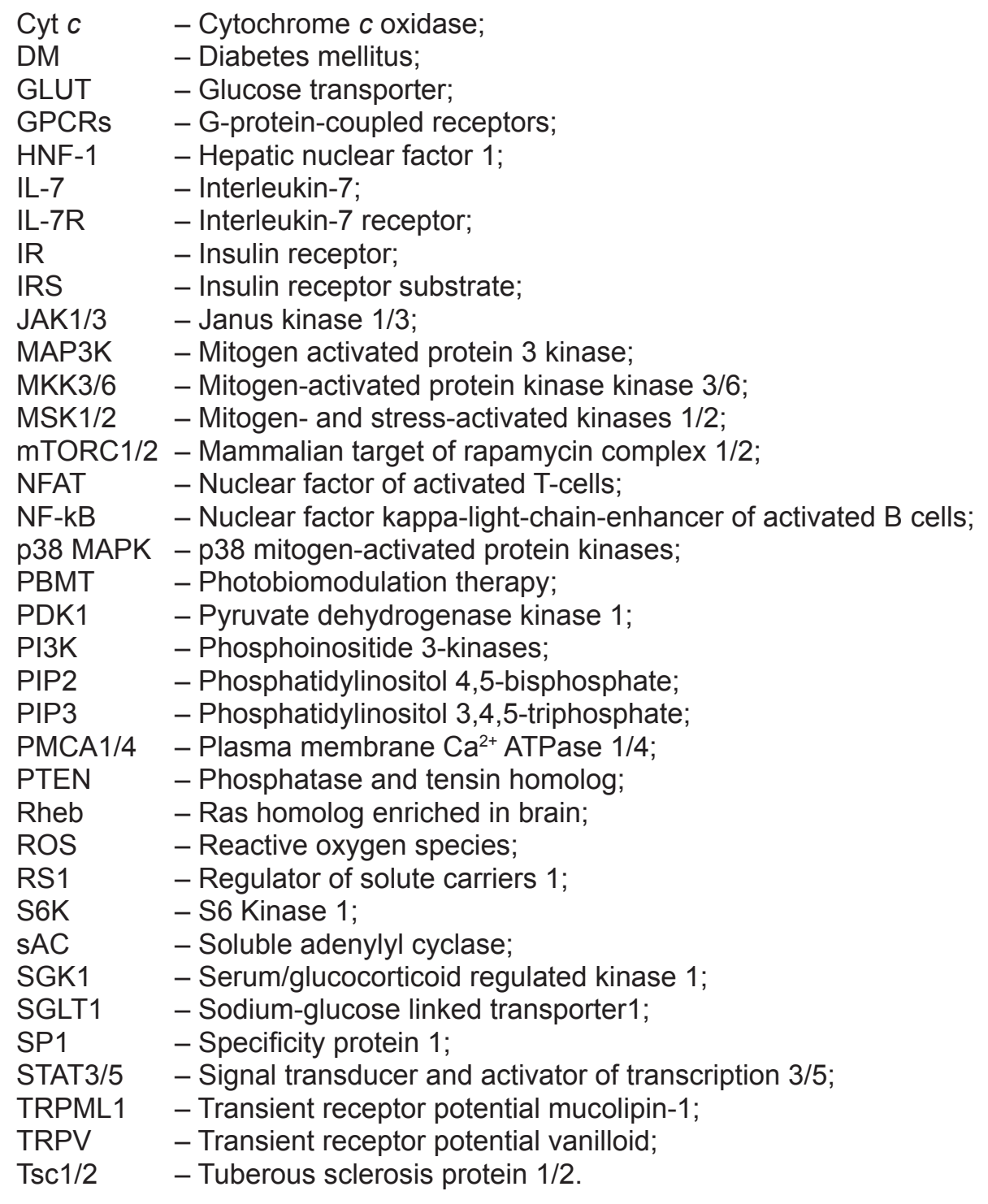

\section{INTRODUCTION}

ATP produced by glycolysis and the electron transport chain is the fuel for the activity and function of any cell. The activation of T cells is accompanied by changes in glucose metabolism. Naïve T lymphocytes are dependent on oxidative phosphorylation for energy, but after stimulation, they differentiate into effector $T$ lymphocytes with the reprogramming of metabolic pathways to glycolysis, and this affects T cells proliferation, activation, and immune function (Zhou et al., 2021). According to Lang et al. (2020), glucose uptake into lymphocytes across the cell membrane is accomplished by nonconcentrative glucose carriers of the GLUT family (GLUT1, GLUT3, GLUT4) which mediate passive transport but are unable to operate against a chemical glucose gradient. Also, Kavanagh et al. (2018) demonstrated the co-expression of GLUT1, GLUT3, 
GLUT4, and GLUT6 in human CD4 ${ }^{+}$T cells after cell activation. Meanwhile, some of the data show that after naïve $T$ lymphocytes differentiate into effector $\mathrm{T}$ cells, they significantly increase the expression of GLUT1 on cell membranes (Zhou et al., 2021; Sinclair, Barthelemy, \& Cantrell, 2020). Besides, there is a report that store-operated calcium entry controls $\mathrm{T}$ cell receptor (TCR)-induced proliferation of T lymphocytes by controlling the expression of GLUT1 and GLUT3, glycolytic enzymes, and proteins required for mitochondrial respiration after stimulation (Vaeth et al., 2017). In this review, we will not pay attention to GLUT6 because there is a study in which authors conclude that GLUT6 does not mediate glucose uptake and localizes on lysosomal membranes (Maedera, Mizuno, Ishiguro, Ito, Soga, \& Kusuhara 2019). Also, Byrne, Olzomer, Brink, \& Hoehn (2018) showed that the knockout of glucose transporter GLUT6 has minimal effects on whole-body energy metabolism in mice. It is noteworthy that some studies demonstrates the influence of elevated glucose concentration in patients with diabetes on lymphocytes' GLUT expression by decreasing GLUT1, GLUT3 and GLUT4 levels, which was more significant for GLUT3 (Kipmen-Korgun, Bilmen-Sarıkçıoglu, Altunbas, Demir, \& Korgun 2009) and GLUT4 (Dou et al., 2016). Facilitated diffusion glucose transporters differ in terms of their levels in cells and regulatory mechanisms that mediate their functioning. They play a vital role in cells' survival and physiological functioning, which makes them a promising therapeutic target for the treatment of diabetes mellitus (DM).

Likewise, there are some reports about $\mathrm{Na}^{+}$coupled glucose carrier SGLT1 mRNA expressions in the lungs, liver, pancreas, and T lymphocytes (Sano, Shinozaki, \& Ohta, 2020). Additionally, Bhavsar et al. (2016) reveal that JAK3 up-regulates SGLT1 by increasing the carrier protein abundance in the cell membrane, an effect enforcing cellular glucose uptake into activated lymphocytes and thus contributing to the immune response. On the other hand, Sano et al. (2020) suggested the possibility of reducing postprandial hyperglycemia in patients with diabetes by reducing glucose absorption in the small intestine using an SGLT1 inhibitor. However, some studies on mice warn of the potential danger of using SGLT1 inhibitors for the treatment of diabetes because the inhibitors may, similarly to genetic knockout of the SGLT1 gene, compromise the macroorganism defense against bacteria and lead to lethal infections (Sharma et al., 2017; Koepsell \& Vallon, 2020). Though, whether humans are similarly sensitive to lack of SGLT1 as mice has not been proven for the time being.

Photobiomodulation therapy (PBMT), also known as low-level light therapy, is commonly used to promote diabetic wound healing (Rajendran, Houreld, \& Abrahamse, 2021; Rahbar Layegh et al., 2020; Oyebode, Houreld, \& Abrahamse, 2021), decreasing inflammation (Ahmadi et al., 2020; Moradi et al, 2020), and produce analgesia (De Freitas \& Hamblin, 2016) using a low-power light source (lasers or light-emitting diodes). The most commonly used wavelength for PBMT was $630-660 \mathrm{~nm}$. The PBMT photons were absorbed by endogenous chromophores that elicit photochemical events without thermal damage (Raizman \& Gavish, 2020). Some data suggest that PBMT modulates gene transcription for protein synthesis and activates cellular signaling (Jere, Houreld, \& Abrahamse, 2020; Rajendran, Houreld, \& Abrahamse, 2021). On the other hand, there are a lot of data in which authors pay more attention to the ability of PBMT to either increase the activity of antioxidant enzymes such as superoxide dismutase (Sunemi et al., 2021), catalase (Karkada, Maiya, Arany, Rao, Adiga, \& Kamath, 2021), as well as the total antioxidant capacity of cells (Chen, Tu, Shi, Wang, Hou, \& Wang, 2021) or to reduce the levels of the proinflammatory cytokine IL-6 and TNF- $\alpha$ in diabetic wound cells (ShaikhKader, Houreld, Rajendran, \& Abrahamse, 2021). It was found that PBMT could affect cell

ISSN 1996-4536 (print) • ISSN 2311-0783 (on-line) • Біологічні Студії / Studia Biologica • 2021 • Том 15 / № 4 • C. 84-104 
functions, such as differentiation (Mokoena, Houreld, Dhilip Kumar, \& Abrahamse, 2019), migration, survival (Jere, Houreld \& Abrahamse, 2021), and metabolism in different cell types, including red blood cells (Walski et al, 2018), endothelial cells (Colombo et al., 2021), hepatic cells (Guo, Gong, Shen, \& Xing, 2020), fibroblasts (Alexandria, de Silva, Maia Filho, Assis, \& Tim 2020), stem cells, osteoblast (Houreld, 2019), and muscle cells (Gong, Zou, Liu, Guo, \& Xin, 2021). Furthermore, several recent studies have concluded that PBMT improves the redox state of mitochondria in diabetic ulcers (Mehrvar et al., 2021; Gopalakrishnan et al., 2020). Additionally, Mussttaf's, Jenkins', \& Jha's (2019) review mentioned that PBMT increases the ability of macrophages to act as phagocytes, stimulates a greater secretion of basic fibroblasts growth factors, and intensifies fibrin resorption as part of the demolition phase of wound healing. Similarly, the above review stated that after PBMT lymphocytes become activated, proliferate more speedily, and become more motile. On the other hand, Karmash, Liuta, Yefimenko, \& Sybirna (2021) demonstrated a decrease in total NO synthase activity and an increased catalase activity in leukocytes of rats with diabetes under PBMT, which prevents the development of oxidative stress. Moreover, Karmash, Liuta, Korobov, \& Sybirna (2020) found that irradiation of rats with DM causes normalization of advanced glycation end product levels in leukocytes. The authors also confirm the ability of PBMT at a wavelength of $630-660 \mathrm{~nm}$ to enhance glucose uptake in leukocytes of rats from both control and diabetic groups. It is noteworthy that Gong et al. (2021) showed a possible mechanism of action of PBMT to improve glucose uptake, which includes reactive oxygen species-induced activation of phosphatase and tensin homolog (PTEN)/protein kinase B (AKT)/GLUT4 translocation signaling pathway in skeletal muscle. However, cellular and molecular mechanisms of enhancing glucose uptake in leukocytes induced by PBMT are not fully understood, and further studies are necessary. This review aims to demonstrate an assumed effect of PBMT on signaling pathways that enhance glucose uptake by SGLT1, GLUT1, GLUT3, and GLUT4 in lymphocytes under both DM and healthy conditions.

Effect of photobiomodulation therapy on the regulation of $\mathrm{Na}^{+}$-coupled glucose carrier SGLT1 in lymphocytes. Summarizing the analyzed literature sources, we created a scheme that visualizes hypothetical mechanisms of the influence of PBMT on the regulation of glucose uptake by SGLT1, both in normal and in diabetic wound lymphocytes (Fig. 1).

Hamblin (2018) and de Freitas \& Hamblin (2016) considered the hypothetical mechanisms of the influence of PBMT on mitochondrial redox signaling. According to their reviews, the leading hypothesis to explain how exactly light increases cytochrome $c$ oxidase enzyme activity is that nitrogen oxide can be photodissociated by absorption of a photon of red light at a wavelength of $630-660 \mathrm{~nm}$. Cytochrome $c$ oxidase is unit IV of the mitochondrial respiratory chain and can be inhibited by noncovalently binding with nitric oxide, which also explains why PBMT has greater effects in diseased or damaged cells in contrast to healthy cells. Thus, PBMT increases adenosine triphosphate (ATP) synthesis and causes resumption of respiration with the generation of reactive oxygen species (ROS) by increasing the mitochondrial membrane potential. One of the direct consequences of the higher level of ATP after PBMT is an increase in cyclic adenosine monophosphate (cAMP) concentration (Zhang, Shen, Wu, Zhang, \& Xing, 2020). It is noteworthy that the generation of CAMP is regulated in two ways: first by adenylate cyclase $(A C)$ in a G-protein-dependent manner, and second by soluble adenylyl cyclase (SAC), the activity of which is induced by $\mathrm{Ca}^{2+}$ with $\mathrm{HCO}_{3}^{-}$in a G-protein-independent manner (Arumugham \& Baldari, 2017; Zhang, Kong, Wang, Jiang, \& Hua, 2020). Also, there is

ISSN 1996-4536 (print) • ISSN 2311-0783 (on-line) • Біологічні Студії / Studia Biologica • 2021 • Том 15 / № 4 • C. 87-104 


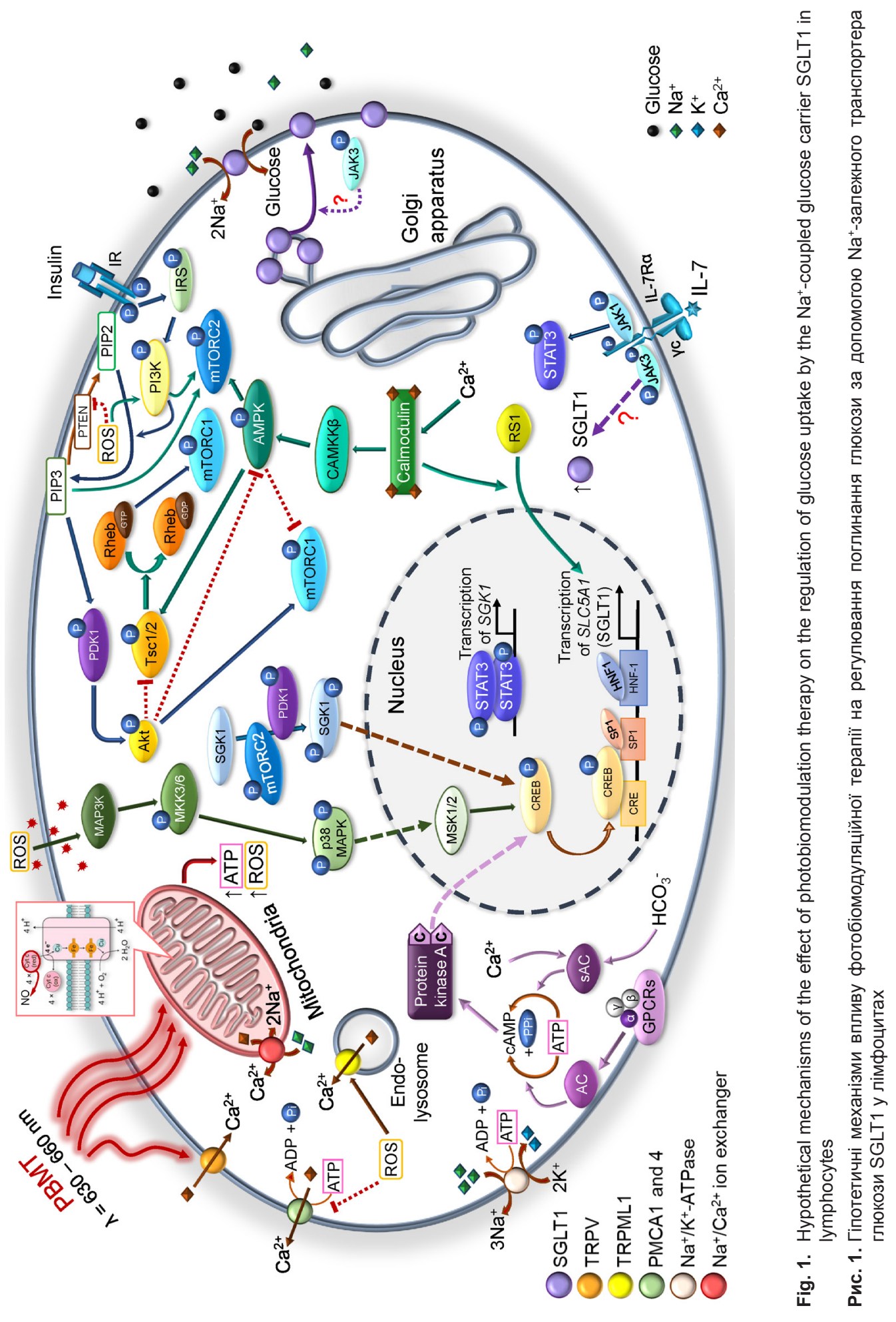

ISSN 1996-4536 (print) • ISSN 2311-0783 (on-line) • Біологічні Студії / Studia Biologica • 2021 • Том 15 / № 4 • C. 84-104 
evidence that irradiation can induce cellular alkalinization, and as a consequence, can facilitate the opening of transient receptor potential vanilloid (TRPV) channels, which leads to an increase in intracellular $\mathrm{Ca}^{2+}$ as shown by fluorescent probes. However, there is a possibility that PBMT can directly activate TRPV channels (De Freitas \& Hamblin, 2016). Besides, it is possible that there is another way to increase intracellular $\mathrm{Ca}^{2+}$ after the effect of PBMT on normal cells through transient receptor potential mucolipin-1 (TRPML1) activation, which is localized in the late endo-lysosome by ROS (Clement, Goodridge, Grimm, Patel, \& Malmberg, 2020), although this needs to be confirmed. In return, under DM conditions a decreased ATP production affects $\mathrm{Na}^{+} / \mathrm{K}^{+}$ATPase activity, so in an attempt to restore cellular $\mathrm{pH}, \mathrm{Na}^{+}$is removed by the $\mathrm{Na}^{+} / \mathrm{Ca}^{2+}$ ion exchanger causing a substantial influx of $\mathrm{Ca}^{2+}$ in lymphocytes (Takeuchi, Kim, \& Matsuoka, 2020). As it is known, PBMT can increase ATP production and thus restore $\mathrm{Na}^{+} / \mathrm{K}^{+}$ATPase activity, which also normalizes $\mathrm{Na}^{+}$and $\mathrm{Ca}^{2+}$ ions intracellular concentration under diabetes (Rhee, Moon, Jung, Oh, Ahn, \& Chung, 2019; Liebert, Krause, Goonetilleke, Bicknell, \& Kiat, 2017). Additionally, it is also possible that an increase in intracellular ATP level after PBMT can promote expelling $\mathrm{Ca}^{2+}$ from lymphocytes through the plasma membrane $\mathrm{Ca}^{2+} \mathrm{ATPase}$ (PMCA) isoforms 1 and 4 , but further studies are needed to confirm this hypothesis. Moreover, Bruce (2018) reviewed that PMCA can be directly inhibited not only by ATP depletion during metabolic stress but also by ROS, so one of the consequences of PBMT influence on normal cells can be inhibition of PMCA with consistent cytosolic $\mathrm{Ca}^{2+}$ increase. The effect of PBMT on the generation of cAMP and changes in intracellular $\mathrm{Ca}^{2+}$ and $\mathrm{Na}^{+}$ ions concentration is shown on the left side of Fig. 1.

An increase in cytosolic $\mathrm{Ca}^{2+}$ by PBMT followed by $\mathrm{Ca}^{+2} /$ calmodulin-dependent kinase $\beta$ (CaMKK $\beta$ ) activation was reported in the study by Guo et al. (2020). CaMKK $\beta$ phosphorylates and activates AMP-activated protein kinase (AMPK) (Kazyken, Lentz, \& Fingar, 2021), which can promote cell survival and metabolic homeostasis by increasing glucose uptake through direct activation of mTOR complex 2 (mTORC2) and inhibition of mTORC1 during energetic stress (Kazyken et al., 2019). Moreover, AMPK can phosphorylate and activate Tsc1/2, which acts as a GTPase-activating protein for Rheb (Ras homolog enriched in brain) and inhibit Rheb activity with a corresponding decrease in mTORC1 activity in lymphocytes, which was demonstrated in the study by Zhang et al. (2019). The described mechanism is shown by green arrows in Fig. 1.

Several studies demonstrated that PBMT can stimulate signaling pathways involving protein kinase B (also known as Akt) in diabetic wound cells (Rajendran et al., 2021; Jere, Houreld, \& Abrahamse, 2019). On the other hand, there is a study by Hamblin (2018) in which the author assumed that the mechanism of Akt activation by PBMT can be related to an increase in ROS generation. Meanwhile, some articles described the ability of ROS to directly activate phosphoinositide 3-kinases (PI3K), amplify its downstream signaling and also concurrently inactivate PTEN, which negatively regulates the synthesis of phosphatidylinositol 3,4,5-triphosphate (PIP3) and thereby inhibits the activation of Akt (Zhang et al., 2016). Another way to activate Akt by PBMT is the insulin signaling pathway. A recent review by Marks (2021) described the ability of PBMT to lower blood glucose concentration and reduce insulin resistance in various types of cells under DM, as well as in the norm. Furthermore, some authors insist that PBMT improved glucose tolerance through the insulin signaling pathway (Gong et al., 2021; Silva et al., 2018). The recent study by Sheccid (2021) demonstrated the capability of PBMT to enhance insulin secretion by $\beta$-cells. Increases in insulin secretion may affect lymphocytes through activation of IR (Insulin receptor) by hormone and, as a consequence, this increased levels of

ISSN 1996-4536 (print) • ISSN 2311-0783 (on-line) • Біологічні Студії / Studia Biologica • 2021 • Том 15 / № 4 • C. $87-104$ 
activated PI3K, pyruvate dehydrogenase kinase 1 (PDK1), Akt. This mechanism is depicted above in Fig. 1. Among other things, recent findings by Dai \& Thomson (2019) suggest that in lymphocytes, mTORC2 can be activated directly by PI3K. Importantly, the activation of Akt requires phosphorylation by mTORC2, but after activation, Akt positively regulates mTORC1 (Pollizzi et al., 2015) and inhibits AMPK (Clement et al., 2020).

On the other hand, there is data by Jere et al. (2020) that demonstrate the ability of PBMT to directly regulate genes that encode for proteins involved in the Janus kinase (JAK)-signal transducer and activator of transcription (STAT) pathway, including Akt, JAK3, JAK1, STAT3, and STAT5. While Akt, JAK1, and STAT5 proteins can take part in mTORC1 activation, which we will explain later, some studies suggested that after phosphorylation of STAT3 mediated by JAK1 and nonreceptor kinases, activated STAT3 can regulate the expression of genes such as serum/glucocorticoid regulated kinase 1 (SGK1) (Zhu, Wang, \& Rui, 2019) and thus take part in enhanced transcription of SGLT1. Moreover, other authors assumed that JAK3 could influence SGLT1 protein abundance in the cell membrane by direct phosphorylation of the carrier protein or by phosphorylation of other signaling molecules, which in turn up-regulated SGLT1 in lymphocytes (Bhavsar et al., 2016). However, the molecular mechanism of the effect of JAK3 on the content of SGLT1 in cells needs to be studied; therefore, we indicated it with red question marks in Fig. 1. We mentioned earlier that the influence of PBMT upregulates JAK3 and JAK1. Also, according to Stabile et al. (2018), both of these proteins are phosphorylated by the interleukin-7 (IL-7) receptor. Phosphorylated JAK3 and JAK1 can stimulate downstream activation of STAT3 and STAT5 in lymphoid cells (Stabile et al., 2018), these proteins are also upregulated by PBMT, so IL-7 can play a significant role in the JAK/STAT pathway activated by PBMT, especially in diabetes due to overproduction of IL-7 (Coulson, Bakhashab, Latief, \& Weaver, 2021), although this also requires further research.

As shown in the review by Koepsell (2020), several factors that regulate the transcription of SGLT1 at the promoter region have been identified, for example, binding of hepatic nuclear factor 1 (HNF1), transcription factor SP1, and CAMP response elementbinding protein (CREB) to the SGLT1 gene. Look at the nucleus shown in Fig. 1. Phosphorylation of CREB is catalyzed by SGK1 (Koepsell, 2017), which has been phosphorylated by PDK1 and mTORC2 (Saravia, Raynor, Chapman, Lim, \& Chi, 2020). Mitogen- and stress-activated kinases (MSK) 1 and 2 are nuclear proteins activated downstream of the p38 MAPK pathways (Martínez-Limón, Joaquin, Caballero, Posas, \& de Nadal, 2020), which is depicted using dark green arrows in Figs. 1. and 2. MSK $1 / 2$ play an important role in CREB activation in lymphocytes, as shown by Kaiser, Wiggin, Lightfoot, Arthur, \& Macdonald (2007). p38 MAPK is activated by a wide range of environmental stimuli that also include oxidative stress (Martínez-Limón et al., 2020). PBMT can increase the activity of enzymatic antioxidants and decrease total NO synthase activity, which leads to a corresponding decrease in the level of oxidative modification of proteins and other markers of oxidative stress in leukocytes of diabetic rats; nevertheless, in healthy animals, the effect of PBMT is the opposite (Karmash et al., 2021; Karmash et al., 2020). Thus, PBMT can influence the p38 MAPK pathway. Furthermore, there is an alternative way how PBMT can increase transcription of SGLT1, namely by increasing CAMP concentration (Hamblin, 2018) and binding of this second messenger to two regulatory subunits of the inactive protein kinase $A$ (PKA) that results in the release and activation of the two catalytic subunits that are able to phosphorylate CREB (Zhang et al., 2020). Additionally, an increase in $\mathrm{Ca}^{2+}$ by PBMT can regulate the nuclear abundance of RS1 (the regulator of solute carriers 1 ), which is

ISSN 1996-4536 (print) • ISSN 2311-0783 (on-line) • Біологічні Студії / Studia Biologica • 2021 • Том 15 / № 4 • C. 84-104 
involved in confluence-dependent regulation of SGLT1 transcription, via nuclear shuttling domain that contains a $\mathrm{Ca}^{2+}$-dependent calmodulin-binding site (Koepsell, 2020).

Thus, PBMT can enhance glucose uptake by the $\mathrm{Na}^{+}$-coupled glucose carrier SGLT1 in lymphocytes of healthy humans by increasing the intracellular concentration of cAMP, $\mathrm{Ca}^{2+}$, ROS and via activating some elements of the JAK/STAT pathway and insulin signaling pathway, ultimately affecting SGLT1 transcription. Possibly, in DM PBMT affects SGLT1 transcription in lymphocytes by reducing oxidative stress through increasing the activity of enzymatic antioxidants, as well as increasing the level of intracellular ATP required for $\mathrm{Na}^{+} / \mathrm{K}^{+}$ATPase activity and therefore stable cells homeostasis. It is noteworthy that PBMT supports the carrier transcription by activating the cAMP/ PKA pathway and other pathways mentioned earlier, but with lower intensity in comparison with processes occurring in diabetic wound cells, which may contribute to the normal cell-mediated protection of the macroorganism, but this requires further research.

Effect of photobiomodulation on the glucose transporters of the GLUT family in lymphocytes. Based on the literature, we created a scheme that demonstrates the hypothetical mechanisms of the influence of PBMT on the regulation of glucose uptake by GLUT1, GLUT3, and GLUT4 in leukocytes of rats from both control and diabetic groups (Fig. 2).

Previously, we noted that in lymphocytes from humans with DM, quantitative contents of GLUT1, GLUT3, and GLUT4 are lower than the content of these glucose transporters in lymphocytes from a healthy human. Furthermore, this difference is more significant for GLUT3 and GLUT4, which might be the cause of the reduced cell-mediated immunity. However, there is conflicting evidence suggesting that upon activation of $B$ cells in DM, they upregulate GLUT1 which is dependent on the action of the transcription factor c-Myc (Wilson \& Moore, 2020). NK cells in diabetes express elevated levels of GLUT4, and, as proposed, the cause of such changes is neutrophil-derived ROS (Daryabor, Atashzar, Kabelitz, Meri, \& Kalantar, 2020). Thus, we consider that it is necessary to conduct more detailed studies of gene expression and exposure of GLUT family proteins on the plasma membrane in different lymphocyte subpopulations.

As discussed earlier, PBMT enhances the expression of JAK1, JAK3, and STAT5 proteins. JAK1 and JAK3 proteins link to the IL-7Ryc (gamma chain of the IL-7 receptor), phosphorylate each other to increase their kinase activity, and then phosphorylate the IL-7R $\alpha$ (alpha chain of the IL-7 receptor), which provides STAT5 binding and phosphorylation (Fig. 2). Activation of the above JAK-STAT pathway promotes glucose uptake by GLUT1 in T (Di Dedda, Vignali, Piemonti, \& Monti, 2019) and B cells (Wilson \& Moore, 2020) that we will explain in more detail. Firstly, phosphorylation of STAT5 proteins results in their dimerization and translocation to the nucleus and finally in the transcription of target genes including c-Myc (González-García, García-Peydró, Alcain, \& Toribio, 2012) and SLC2A1 (GLUT1) (Di Dedda et al., 2019). c-Myc itself also regulates gene expression of key metabolic enzymes (Kress, Sabò, Amati, 2015) and SLC2A1 (Siska \& Rathmell, 2015). Secondly, evidence suggests that STAT5 can directly bind to consensus sites within the Akt gene and enhance its transcriptional activation, but the phosphorylation of p38 negatively correlates with the phosphorylation of STAT5 (Tian et al., 2020). At the same time, activation of Akt plays a central role in regulating GTUT1 vesicle trafficking (Di Dedda et al., 2019) and stabilization (Avanzato et al., 2018) at the plasma membrane, leading to an increase in GLUT1 surface exposure. Furthermore, induction of GLUT1 regulation on the transcriptional level in lymphocytes may occur through the PI3K-AktmTORC1 pathway that regulates the key metabolic transcription factor c-Myc (Shyer,

ISSN 1996-4536 (print) • ISSN 2311-0783 (on-line) • Біологічні Студії / Studia Biologica • 2021 • Том 15 / № 4 • C. $87-104$ 


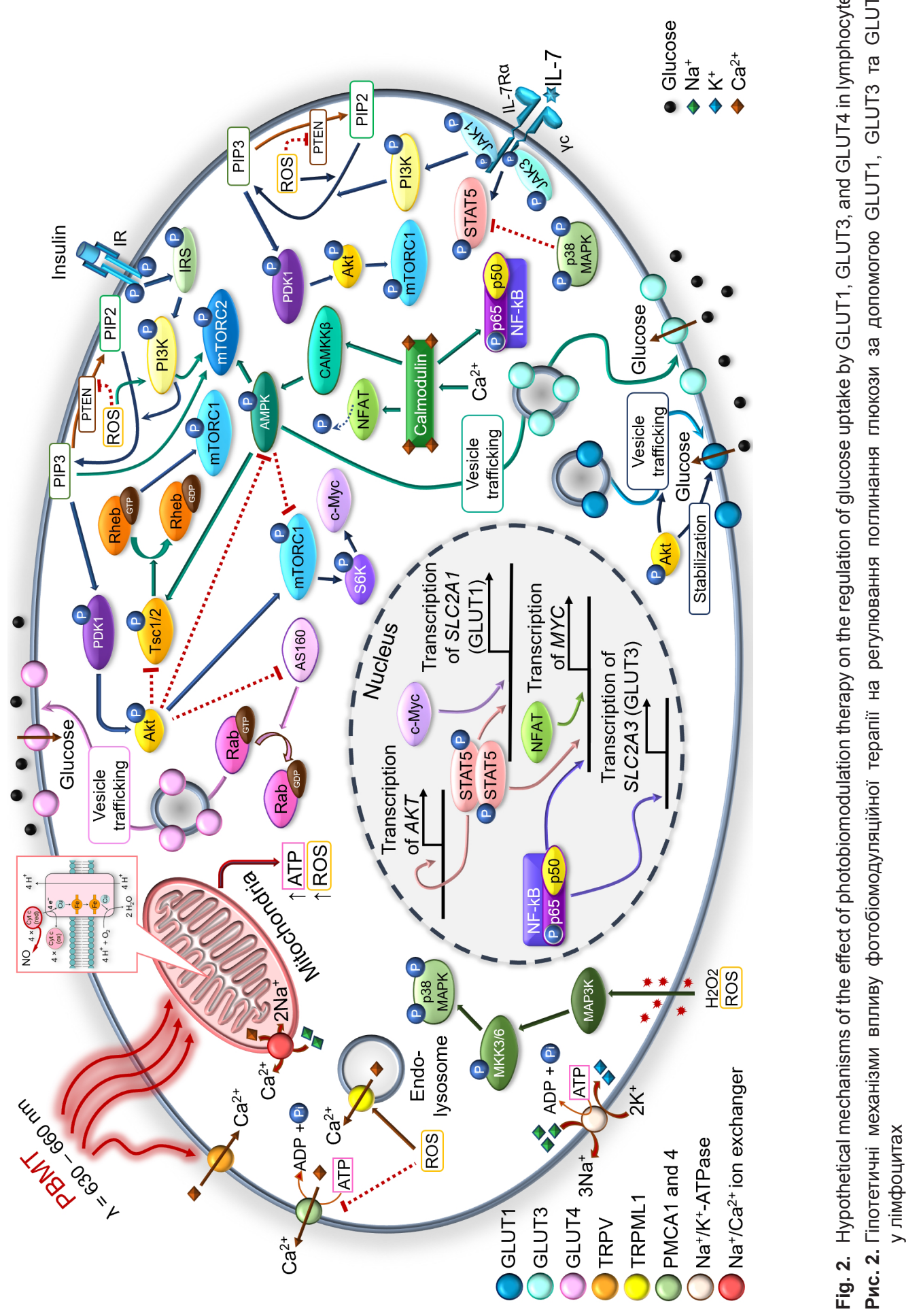

ISSN 1996-4536 (print) • ISSN 2311-0783 (on-line) • Біологічні Студії / Studia Biologica • 2021 • Том 15 / № 4 • C. 84-104 
Flavell, \& Bailis, 2020). In particular, phosphorylation of mTORC1 substrate S6 Kinase 1 (S6K1) can mediate MYC mRNA stability, translation, and protein stability (Shorning, Dass, Smalley, \& Pearson, 2020). Alternatively, in the review by de Barrios, Meler, \& Parra (2020) it is mentioned that phosphorylated STAT5 may cooperate with JAK2 to maintain an elevated level of c-Myc by protecting it from ubiquitin-dependent degradation. Besides, one of the main pathways activated by JAK1 is the PI3K/Akt/mTORC1, where JAK1 induces phosphorylation of the IL-7Ra intracellular domain and promotes PI3K recruitment with consequent activation (Oliveira, Akkapeddi, Ribeiro, Melão, Barata, 2019).

Among the targets of intracellular $\mathrm{Ca}^{2+}$ in lymphocytes are $\mathrm{Ca}^{2+}$-regulated transcription factors, including the Nuclear factor of activated T-cells (NFAT) and Nuclear factor kappa-light-chain-enhancer of activated B cells (NF-kB) (Berry, May, \& Freedman, 2018). As has been found, the enhanced activity of NF-kB upregulates glucose transporters GLUT3 (Kawauchi, Araki, Tobiume, \& Tanaka, 2008) and GLUT1 (Ziegler, Almos, McNeill, Jansch, \& Lesch, 2020) in lymphocytes. While NF-kB stimulates GLUT3 transcription by binding to a specific NF-KB binding element located within the intron of the SLC2A3 (GLUT3) (Ancey, Contat, \& Meylan, 2018), the stimulation of GLUT1 transcription enhances upon the regulation of the c-Myc gene transcription by NF-kB and NFAT (Berry et al., 2018). Look at the nucleus shown in Fig. 2. On the other hand, data by Berry et al. (2018) introduced a significant possibility that c-Myc expression in T cells is induced by NFAT-independent manner compared to the transcriptional regulation of the c-Myc gene by NF-kB/NFAT in B cells. According to Hogan, Chen, Nardone, \& Rao (2003), $\mathrm{Ca}^{2+}$ I calmodulin-dependent serine phosphatase calcineurin dephosphorylates NFAT upon rising intracellular $\mathrm{Ca}^{2+}$ concentration, after which dephosphorylated NFAT translocate to the nucleus and become transcriptionally active, thus providing a direct link between intracellular $\mathrm{Ca}^{2+}$ and gene expression. On the contrary, calmodulin directly binds to NF-kB p65 and lets it translocate to the nucleus and act on its target genes in $\mathrm{T}$ and $\mathrm{B}$ lymphocytes, including MYC and SLC2A3 (Berry et al., 2018). In addition to an increase in transcriptions of GLUT1 and GLUT3, PBMT may also increase translocation of GLUT3 to the plasma membrane through activation of AMPK, because as has been shown by Chan, Burke, Gao, \& Fish (2012), activated AMPK is also able to stimulate glycolysis through GLUT3 trafficking and phosphorylation/activation of the glycolytic enzymes.

Another way in which PBMT increases glucose uptake in leukocytes includes activation of Akt, which can inactivate the AS160 protein (Rab GTPase-activating protein) by phosphorylation that results in the translocation of GLUT4 containing vesicles on the cell surface according to the current understanding of GLUT4 translocation mechanisms by Wang, Wang, Hu, Huang, \& Chen, (2020). This mechanism is depicted by pink arrows in Fig. 2. Also, there is evidence in support of this hypothesis in different cells, including adipocytes (Silva et al., 2018), myocytes (Gong et al., 2021), and lymphocytes (Karmash et al., 2020).

Therefore, PBMT can increase intracellular ROS and $\mathrm{Ca}^{2+}$ concentration, enhance NF-kB translocation to the nucleus, mediate MYC mRNA transcription and protein stability in normal cells, which correspondingly upregulate GLUT1 and GLUT3 genes in lymphocytes. Additionally, PBMT improves vesicle trafficking for GLUT4 and GLUT1 transporters in cells from healthy groups via phosphorylated Akt in insulin-stimulated and IL-7-stimulated pathways. Although PBMT may increase translocation of GLUT3 to the plasma membrane through activation of AMPK by CAMKK $\beta$, this mechanism may be insignificant compared to activation of AMPK by AMP, which is tightly associated with cell activation as a response to a substantial increase in energy need. Notably, activation of

ISSN 1996-4536 (print) • ISSN 2311-0783 (on-line) • Біологічні Студії / Studia Biologica • 2021 • Том 15 / № 4 • C. $87-104$ 
AMPK by AMP is theoretically crucial for GLUT3 translocation, and so elevated ATP content in lymphocytes after PBMT contradicts this pathway. It is possible that in diabetes, PBMT has the opposite effect compared to the influence of therapy on the lymphocytes of a healthy body. Probably PBMT does not significantly affect GLUT3 gene expression and may reduce GLUT3 exposure on the plasma membrane in lymphocytes in DM because PBMT causes a decrease in NF-KB translocation into the nucleus, AMPK inhibition by Akt, and a rise in intracellular ATP concentration. Thus, this mechanism requires further research. On the other hand, the effect of PBMT on oxidatively stressed cells in diabetes reduces the level of ROS (Hamblin, 2017) and increases the level of phosphorylated Akt, which leads to increased vesicle trafficking of GLUT1 and GLUT4. Moreover, elevated levels of phosphorylated mTORC1 and STAT5 by PBMT provide GLUT1 upregulation through metabolic transcription factor c-Myc, as discussed earlier.

\section{CONCLUSION}

PBMT can significantly influence glucose uptake by various glucose transporters, including SGLT1, GLUT1, GLUT3, and GLUT4 in normal and diabetic lymphocytes. Many molecular mechanisms of glucose uptake regulation in lymphocytes are not fully understood and need further investigation, especially signaling pathways induced by PBMT.

\section{ACKNOWLEDGMENTS AND FUNDING SOURCES}

This review did not receive any particular grant from any financial organizations in the state, commercial, or noncommercial sectors.

\section{COMPLIANCE WITH ETHICAL STANDARDS}

Conflict of Interest: The authors declare that the research was conducted in the absence of any commercial or financial relationships that could be construed as a potential conflict of interest.

\section{AUTHOR CONTRIBUTIONS}

Conceptualization, [S.N.O.; L.M.Ya]; methodology, [-]; validation, [-]; formal analysis, [-]; investigation, [M.A.O.]; resources, [M.A.O.; L.M.Ya; S.N.O]; data curation, [-]; writing - original draft preparation, [M.A.O.]; writing - review and editing, [S.N.O.; L.M.Ya]; visualization, [M.A.O.] supervision, [S.N.O.]; project administration, [S.N.O.]; funding acquisition, [-]. All authors have read and agreed to the published version of the manuscript.

\section{REFERENCES}

Ahmadi, H., Amini, A., Fadaei Fathabady, F., Mostafavinia, A., Zare, F., Ebrahimpour-Malekshah, R., Ghalibaf, M. N., Abrisham, M., Rezaei F., Albright, R., Ghoreishi, S. K., Chien, S., \& Bayat, M. (2020) Transplantation of photobiomodulation-preconditioned diabetic stem cells accelerates ischemic wound healing in diabetic rats. Stem Cell Research \& Therapy, 11(1), 494. doi:10.1186/s13287-020-01967-2

Crossref • PubMed • PMC • Google Scholar

Alexandria, F. E. D., de Silva, N. C., Maia Filho, A. L. M., Assis, L., \& Tim, C. R. (2020) Wound healing in diabetic: a review of photobiomodulation therapy applications. Research, Society and Development, 9(10), e259108310. doi:10.33448/rsd-v9i10.8310

Crossref $\bullet$ Google Scholar

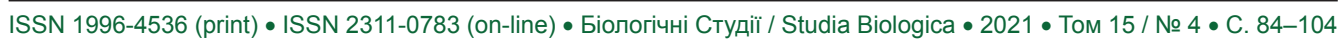


Ancey, P. B., Contat, C., \& Meylan, E. (2018). Glucose transporters in cancer - from tumor cells to the tumor microenvironment. FEBS Journal, 285(16), 2926-2943. doi:10.1111/febs.14577 Crossref • PubMed $\bullet$ Google Scholar

Arumugham, V. B. \& Baldari, C. T. (2017). cAMP: a multifaceted modulator of immune synapse assembly and T cell activation. Journal of Leukocyte Biology, 101(6), 1301-1316. doi:10.1189/ jlb.2RU1116-474R

Crossref $\bullet$ PubMed $\bullet$ Google Scholar

Avanzato, D., Pupo, E., Ducano, N., Isella, C., Bertalot, G., Luise, C., Pece, S., Bruna, A., Rueda, O. M., Caldas, C., Di Fiore, P. P., Sapino, A., \& Lanzetti, L. (2018). High USP6NL levels in breast cancer sustain chronic AKT phosphorylation and GLUT1 stability fueling aerobic glycolysis. Cancer Research, 78(13), 3432-3444. doi:10.1158/0008-5472.CAN-17-3018 Crossref $\bullet$ PubMed $\bullet$ Google Scholar

Berry, C. T., May, M. J., \& Freedman, B. D. (2018). STIM- and Orai-mediated calcium entry controls NF-KB activity and function in lymphocytes. Cell Calcium, 74, 131-143. doi:10.1016/j. ceca.2018.07.003

Crossref $\bullet$ PubMed $\bullet$ PMC $\bullet$ Google Scholar

Bhavsar, S. K., Singh, Y., Sharma, P., Khairnar, V., Hosseinzadeh, Z., Zhang, S., Palmada, M., Sabolic, I., Koepsell, H., Lang, K. S., Lang, P. A., \& Lang, F. (2016). Expression of JAK3 sensitive $\mathrm{Na}^{+}$coupled glucose carrier SGLT1 in activated cytotoxic T lymphocytes. Cellular Physiology and Biochemistry, 39(3), 1209-1228. doi:10.1159/000447827

Crossref • PubMed • Google Scholar

Bruce, J. I. E. (2018). Metabolic regulation of the PMCA: Role in cell death and survival. Cell Calcium, 69, 28-36. doi:10.1016/j.ceca.2017.06.001

Crossref $\bullet$ PubMed $\bullet$ PMC $\bullet$ Google Scholar

Byrne, F. L., Olzomer, E. M., Brink, R., \& Hoehn, K. L. (2018). Knockout of glucose transporter GLUT6 has minimal effects on whole body metabolic physiology in mice. American Journal of Physiology-Endocrinology and Metabolism, 315(2), E286-E293. doi:10.1152/ajpendo.00082.2018 Crossref $\bullet$ PubMed $\bullet$ Google Scholar

Chan, O, Burke, J. D., Gao, D. F., \& Fish, E. N. (2012). The chemokine CCL5 regulates glucose uptake and AMP kinase signaling in activated T cells to facilitate chemotaxis. Journal of Biological Chemistry, 287(35), 29406-16. doi:10.1074/jbc.M112.348946

Crossref $\bullet$ PubMed $\bullet$ PMC $\bullet$ Google Scholar

Chen, H., Tu, M., Shi, J., Wang, Y., Hou, Z., \& Wang, J. (2021). Effect of photobiomodulation on CCC-ESF reactive oxygen species steady-state in high glucose mediums. Lasers in Medical Science, 36(3), 555-562. doi:10.1007/s10103-020-03057-4

Crossref $\bullet$ PubMed $\bullet$ Google Scholar

Clement, D., Goodridge, J. P., Grimm, C., Patel, S., \& Malmberg, K. J. (2020). TRP channels as interior designers: remodeling the endolysosomal compartment in natural killer cells. Frontiers in Immunology, 11, 753. doi:10.3389/fimmu.2020.00753

Crossref $\bullet$ PubMed $\bullet$ PMC $\bullet$ Google Scholar

Colombo, E., Signore, A., Aicardi, S., Zekiy, A., Utyuzh, A., Benedicenti, S., \& Amaroli, A. (2021). Experimental and clinical applications of red and near-infrared photobiomodulation on endothelial dysfunction: A review. Biomedicines, 9(3), 274. doi:10.3390/biomedicines 9030274

Crossref $\bullet$ PubMed $\bullet$ PMC $\bullet$ Google Scholar

Coulson, D. J., Bakhashab, S., Latief, J. S., \& Weaver, J. U. (2021). MiR-126, IL-7, CXCR1/2 receptors, inflammation and circulating endothelial progenitor cells: The study on targets for treatment pathways in a model of subclinical cardiovascular disease (type 1 diabetes mellitus). Journal of Translational Medicine, 19(1), 140. doi:10.1186/s12967-021-02785-7

Crossref $\bullet$ PubMed $\bullet$ PMC $\bullet$ Google Scholar

Dai, H. \& Thomson, A. W. (2019). The "other" mTOR complex: New insights into mTORC2 immunobiology and their implications. American Journal of Transplantation, 19(6), 1614-1621. doi:10.1111/ajt.15320

Crossref • PubMed • PMC • Google Scholar

ISSN 1996-4536 (print) • ISSN 2311-0783 (on-line) • Біологічні Студії / Studia Biologica • 2021 • Том 15 / № 4 • C. $87-104$ 
Daryabor, G., Atashzar, M. R., Kabelitz, D., Meri, S., \& Kalantar, K. (2020). The effects of type 2 diabetes mellitus on organ metabolism and the immune system. Frontiers in Immunology, 11, 1582. doi:10.3389/fimmu.2020.01582

Crossref $\bullet$ PubMed $\bullet$ PMC $\bullet$ Google Scholar

De Barrios, O., Meler, A., \& Parra, M. (2020). MYC's fine line between B cell development and malignancy. Cells, 9(2), 523. doi:10.3390/cells9020523

Crossref $\bullet$ PubMed $\bullet$ PMC $\bullet$ Google Scholar

De Freitas, L. F. \& Hamblin, M. R. (2016). Proposed mechanisms of photobiomodulation or lowlevel light therapy. IEEE Journal of Selected Topics in Quantum Electronics, 22(3), 7000417. doi:10.1109/JSTQE.2016.2561201

Crossref $\bullet$ PubMed $\bullet$ PMC $\bullet$ Google Scholar

Di Dedda, C., Vignali, D., Piemonti, L., \& Monti, P. (2019). Pharmacological targeting of GLUT1 to control autoreactive T cell responses. International Journal of Molecular Sciences, 20(19), 4962. doi:10.3390/ijms20194962

Crossref • PubMed • PMC • Google Scholar

Dou, M., Ma, Y., Ma, A. G., Han, L., Song, M. M., Wang, Y. G., Yao, M. X., Sun, X. F., Li, Y., Gao, S., \& Zhang, Y. (2016). Combined chromium and magnesium decreases insulin resistance more effectively than either alone. Asia Pacific Journal of Clinical Nutrition, 25(4), 747-753. doi:10.6133/apjcn.092015.48

Crossref $\bullet$ PubMed $\bullet$ Google Scholar

Gong, L., Zou, Z., Liu, L., Guo, S., \& Xin, D. (2021). Photobiomodulation therapy ameliorates hyperglycemia and insulin resistance by activating cytochrome $c$ oxidase-mediated protein kinase B in muscle. Aging (Albany NY), 13(7), 10015-10033. doi:10.18632/aging.202760 Crossref • PubMed • PMC • Google Scholar

González-García, S., García-Peydró, M., Alcain, J., \& Toribio, M. L. (2012). Notch1 and IL-7 receptor signalling in early T-cell development and leukaemia. Current Topics in Microbiology and Immunology, 360, 47-73. doi:10.1007/82_2012_231

Crossref • PubMed • Google Scholar

Gopalakrishnan, S., Mehrvar, S., Maleki, S., Schmitt, H., Summerfelt, P., Dubis, A. M., Abroe, B., Connor, T. B. Jr., Carroll, J., Huddleston, W., Ranji, M., \& Eells, J. T. (2020). Photobiomodulation preserves mitochondrial redox state and is retinoprotective in a rodent model of retinitis pigmentosa. Scientific Reports, 10(1), 20382. doi:10.1038/s41598-020-77290-w

Crossref • PubMed • PMC • Google Scholar

Guo, S., Gong, L., Shen, Q., \& Xing, D. (2020). Photobiomodulation reduces hepatic lipogenesis and enhances insulin sensitivity through activation of CaMKK $/$ AMPK signaling pathway. Journal of Photochemistry and Photobiology B, 213, 112075. doi:10.1016/j.jphotobiol.2020.112075 Crossref • PubMed • Google Scholar

Hamblin, M. R. (2017). Mechanisms and applications of the anti-inflammatory effects of photobiomodulation. AIMS Biophysics, 4(3), 337-361. doi:10.3934/biophy.2017.3.337

Crossref $\bullet$ PubMed $\bullet$ PMC $\bullet$ Google Scholar

Hamblin, M. R. (2018). Mechanisms and mitochondrial redox signaling in photobiomodulation. Photochemistry and Photobiology, 94(2), 199-212. doi:10.1111/php.12864

Crossref $\bullet$ PubMed $\bullet$ PMC $\bullet$ Google Scholar

Hogan, P. G., Chen, L., Nardone, J., \& Rao, A. (2003). Transcriptional regulation by calcium, calcineurin, and NFAT. Genes \& Development, 17(18), 2205-32. doi:10.1101/gad.1102703 Crossref $\bullet$ PubMed $\bullet$ Google Scholar

Houreld, N. N. (2019). Healing effects of photobiomodulation on diabetic wounds. Applied Sciences, 9(23), 5114. doi:10.3390/app9235114

Crossref $\bullet$ Google Scholar

Jere, S. W., Houreld, N. N., \& Abrahamse, H. (2019). Role of the PI3K/AKT (mTOR and GSK3ß) signalling pathway and photobiomodulation in diabetic wound healing. Cytokine \& Growth Factor Reviews, 50, 52-59. doi:10.1016/j.cytogfr.2019.03.001

Crossref • PubMed • Google Scholar

ISSN 1996-4536 (print) • ISSN 2311-0783 (on-line) • Біологічні Студії / Studia Biologica • 2021 • Том 15 / № 4 • C. 84-104 
Jere, S. W., Houreld, N. N., \& Abrahamse, H. (2020). Photobiomodulation and the expression of genes related to the JAK/STAT signalling pathway in wounded and diabetic wounded cells. Journal of Photochemistry and Photobiology B, 204, 111791. doi:10.1016/j.jphotobiol.2020.111791 Crossref $\bullet$ PubMed $\bullet$ Google Scholar

Jere, S. W., Houreld, N. N., \& Abrahamse, H. (2021). Effect of photobiomodulation on cellular migration and survival in diabetic and hypoxic diabetic wounded fibroblast cells. Lasers in Medical Science. 2021, 36(2), 365-374. doi:10.1007/s10103-020-03041-y

Crossref $\bullet$ PubMed $\bullet$ Google Scholar

Kaiser, M., Wiggin, G. R., Lightfoot, K., Arthur, J. S., \& Macdonald, A. (2007). MSK regulate TCRinduced CREB phosphorylation but not immediate early gene transcription. European Journal of Immunology, 37(9), 2583-95. doi:10.1002/eji.200636606

Crossref $\bullet$ PubMed $\bullet$ Google Scholar

Karkada, G., Maiya, G. A., Arany, P., Rao, M., Adiga, S., \& Kamath, S. U. (2021). Effect of photobiomodulation therapy on oxidative stress markers in healing dynamics of diabetic neuropathic wounds in Wistar rats. Cell Biochemistry and Biophysics. doi:10.1007/s12013-021-01021-9 Crossref $\bullet$ PubMed $\bullet$ Google Scholar

Karmash, O. I., Liuta, M. Ya., Korobov, A. M., \& Sybirna N. O. (2020). The effect of photobiomodulation therapy on oxidative stress progressing in blood leukocytes of streptozotocininduced diabetic rats. Cytology and Genetics, 54(5), 97-107. doi:10.3103/S0095452720050114 [In Ukrainian]

Crossref • Google Scholar

Karmash, O. I., Liuta, M. Ya., Yefimenko N. V., \& Sybirna N. O. (2021) The effect of photobiomodulation therapy on some indices of rats' blood cells functional state under experimental diabetes mellitus. Studia Biologica, 15(3), 3-16. doi:10.30970/sbi.1503.659

Crossref $\bullet$ Google Scholar

Kavanagh, W. M, Coombes, N., Juszczak, F., Athanasopoulos, M., Khan, M. B., Eykyn, T. R., Srenathan, U., Taams, L. S., Dias, Z. J., Da Poian, A. T., \& Huthoff, H. (2018). Upregulation of glucose uptake and hexokinase activity of primary human CD4+ T cells in response to infection with HIV-1. Viruses, 10(3), 114. doi:10.3390/v10030114

Crossref • PubMed • PMC • Google Scholar

Kawauchi, K., Araki, K., Tobiume, K., \& Tanaka, N. (2008). p53 regulates glucose metabolism through an IKK-NF-kappaB pathway and inhibits cell transformation. Nature Cell Biology, 10(5), 611-8. doi:10.1038/ncb1724

Crossref $\bullet$ PubMed $\bullet$ Google Scholar

Kazyken, D., Lentz, S. I., \& Fingar, D. C. (2021). Alkaline intracellular pH (pHi) activates AMPKmTORC2 signaling to promote cell survival during growth factor limitation. Journal of Biological Chemistry, 297(4), 101100. doi:10.1016/j.jbc.2021.101100

Crossref $\bullet$ PubMed $\bullet$ PMC $\bullet$ Google Scholar

Kazyken, D., Magnuson, B., Bodur, C., Acosta-Jaquez, H. A., Zhang, D., Tong, X., Barnes, T. M., Steinl, G. K., Patterson, N. E., Altheim, C. H., Sharma, N., Inoki, K., Cartee, G. D., Bridges, D., Yin, L., Riddle, S. M., \& Fingar, D. C. (2019). AMPK directly activates mTORC2 to promote cell survival during acute energetic stress. Science Signaling, 12(585), eaav3249. doi:10.1126/ scisignal.aav3249

Crossref $\bullet$ PubMed $\bullet$ PMC $\bullet$ Google Scholar

Kipmen-Korgun, D., Bilmen-Sarıkçığlu, S., Altunbas, H., Demir, R., \& Korgun, E. T. (2009). Type-2 diabetes down-regulates glucose transporter proteins and genes of the human blood leukocytes. Scandinavian Journal of Clinical and Laboratory Investigation, 69(3), 350-358. doi:10.1080/00365510802632163

Crossref $\bullet$ PubMed $\bullet$ Google Scholar

Koepsell, H. \& Vallon, V. (2020). A special issue on glucose transporters in health and disease. Pflügers Archiv, 472(9), 1107-1109. doi:10.1007/s00424-020-02442-w

Crossref • PubMed • PMC • Google Scholar

Koepsell, H. (2017). The Na+-D-glucose cotransporters SGLT1 and SGLT2 are targets for the treatment of diabetes and cancer. Pharmacology \& Therapeutics, 170, 148-165. doi:10.1016/j. pharmthera.2016.10.017

Crossref • PubMed • Google Scholar

ISSN 1996-4536 (print) •ISSN 2311-0783 (on-line) • Біологічні Студії / Studia Biologica • 2021 • Том 15 / № 4 • C. 87-104 
Koepsell, H. (2020). Glucose transporters in the small intestine in health and disease. Pflügers Archiv, 472(9), 1207-1248. doi:10.1007/s00424-020-02439-5

Crossref $\bullet$ PubMed $\bullet$ PMC $\bullet$ Google Scholar

Kress, T. R., Sabò, A., \& Amati, B. (2015). MYC: connecting selective transcriptional control to global RNA production. Nature Reviews Cancer, 15(10), 593-607. doi:10.1038/nrc3984 Crossref $\bullet$ PubMed $\bullet$ Google Scholar

Lang, F., Singh, Y., Salker, M. S., Ma, K., Pandyra, A. A., Lang, P. A., \& Lang, K. S. (2020). Glucose transport in lymphocytes. Pflügers Archiv, 472(9), 1401-1406. doi:10.1007/s00424020-02416-y

Crossref $\bullet$ PubMed $\bullet$ Google Scholar

Liebert, A., Krause, A., Goonetilleke, N., Bicknell, B., \& Kiat, H. (2017). A role for photobiomodulation in the prevention of myocardial ischemic reperfusion injury: A systematic review and potential molecular mechanisms. Scientific Reports, 7, 42386. doi:10.1038/srep42386

Crossref $\bullet$ PubMed $\bullet$ PMC $\bullet$ Google Scholar

Maedera, S., Mizuno, T., Ishiguro, H., Ito, T., Soga, T., \& Kusuhara, H. (2019). GLUT6 is a lysosomal transporter that is regulated by inflammatory stimuli and modulates glycolysis in macrophages. FEBS Letters, 593(2), 195-208. doi:10.1002/1873-3468.13298

Crossref $\bullet$ PubMed $\bullet$ Google Scholar

Marks, R. (2021). Photobiomodulation: a potential adjunctive obesity intervention a review. Advances in Obesity, Weight Management \& Control, 11(4), 135-139. doi:10.15406/ aowmc.2021.11.00347

Crossref $\bullet$ Google Scholar

Martínez-Limón, A., Joaquin, M., Caballero, M., Posas, F., \& de Nadal, E. (2020). The p38 pathway: from biology to cancer therapy. International Journal of Molecular Sciences, 21(6), 1913. doi:10.3390/ijms21061913

Crossref $\bullet$ PubMed $\bullet$ PMC $\bullet$ Google Scholar

Mehrvar, S., Mostaghimi, S., Foomani, F. H., Abroe, B., Eells, J. T., Gopalakrishnan, S., \& Ranji, M. (2021). $670 \mathrm{~nm}$ photobiomodulation improves the mitochondrial redox state of diabetic wounds. Quantitative Imaging in Medicine and Surgery, 11(1), 107-118. doi:10.21037/qims-20-522 Crossref $\bullet$ PubMed $\bullet$ PMC $\bullet$ Google Scholar

Mokoena, D. R., Houreld, N. N., Dhilip Kumar, S. S., \& Abrahamse, H. (2020). Photobiomodulation at $660 \mathrm{~nm}$ stimulates fibroblast differentiation. Lasers in Surgery and Medicine, 52(7), 671681. doi:10.1002/lsm.23204

Crossref $\bullet$ PubMed $\bullet$ Google Scholar

Moradi, A., Zare, F., Mostafavinia, A., Safaju, S., Shahbazi, A., Habibi, M., Abdollahifar, M. A., Hashemi, S. M., Amini, A., Ghoreishi, S. K., Chien, S., Hamblin, M. R., Kouhkheil, R., \& Bayat, M. (2020). Photobiomodulation plus adipose-derived stem cells improve healing of ischemic infected wounds in type 2 diabetic rats. Scientific Reports, 10(1), 1206. doi:10.1038/ s41598-020-58099-z

Crossref $\bullet$ PubMed $\bullet$ PMC $\bullet$ Google Scholar

Mussttaf, R. A., Jenkins, D. F. L., \& Jha, A. N. (2019). Assessing the impact of low level laser therapy (LLLT) on biological systems: a review. International Journal of Radiation Biology, 95(2), 120-143. doi:10.1080/09553002.2019.1524944

Crossref $\bullet$ PubMed $\bullet$ Google Scholar

Oliveira, M. L, Akkapeddi, P., Ribeiro, D., Melão, A., \& Barata, J. T. (2019). IL-7R-mediated signaling in T-cell acute lymphoblastic leukemia: An update. Advances in Biological Regulation, 71, 88-96. doi:10.1016/j.jbior.2018.09.012

Crossref $\bullet$ PubMed $\bullet$ PMC $\bullet$ Google Scholar

Oyebode, O., Houreld, N. N., \& Abrahamse, H. (2021). Photobiomodulation in diabetic wound healing: A review of red and near-infrared wavelength applications. Cell Biochemistry and Function, 39(5), 596-612. doi:10.1002/cbf.3629

Crossref $\bullet$ PubMed $\bullet$ Google Scholar

Pollizzi, K. N., Patel, C. H., Sun, I. H., Oh, M. H., Waickman, A. T., Wen, J., Delgoffe, G. M., \& Powell, J. D. (2015). mTORC1 and mTORC2 selectively regulate CD8 ${ }^{+} \mathrm{T}$ cell differentiation. Journal of Clinical Investigation, 125(5), 2090-2108. doi:10.1172/JCI77746

Crossref $\bullet$ PubMed $\bullet$ PMC $\bullet$ Google Scholar

ISSN 1996-4536 (print) • ISSN 2311-0783 (on-line) • Біологічні Студії / Studia Biologica • 2021 • Том 15 / № 4 • C. 84-104 
Rahbar Layegh, E., Fadaei Fathabadi, F., Lotfinia, M., Zare, F., Mohammadi Tofigh, A., Abrishami, S., \& Piryaei, A. (2020). Photobiomodulation therapy improves the growth factor and cytokine secretory profile in human type 2 diabetic fibroblasts. Journal of Photochemistry and Photobiology B: Biology, 210, 111962. doi:10.1016/j.jphotobiol.2020.111962

Crossref $\bullet$ PubMed $\bullet$ Google Scholar

Raizman, R. \& Gavish, L. (2020). At-home self-applied photobiomodulation device for the treatment of diabetic foot ulcers in adults with type 2 diabetes: Report of 4 cases. Canadian Journal of Diabetes, 44(5), 375-378. doi:10.1016/j.jcjd.2020.01.010

Crossref $\bullet$ PubMed $\bullet$ Google Scholar

Rajendran, N. K., Houreld, N. N., \& Abrahamse, H. (2021). In vitro wound healing potential of photobiomodulation is possibly mediated by its stimulatory effect on AKT expression in adiposederivedstemcells. Oxidative MedicineandCellularLongevity,6664627.doi:10.1155/2021/6664627 Crossref $\bullet$ PubMed $\bullet$ PMC $\bullet$ Google Scholar

Rajendran, N. K., Houreld, N. N., \& Abrahamse, H. (2021). Photobiomodulation reduces oxidative stress in diabetic wounded fibroblast cells by inhibiting the FOXO1 signaling pathway. Journal of Cell Communication and Signaling, 15(2), 195-206. doi:10.1007/s12079-020-00588-x

Crossref $\bullet$ PubMed $\bullet$ PMC $\bullet$ Google Scholar

Rhee, Y. H., Moon, J. H., Jung, J. Y., Oh, C., Ahn, J. C., \& Chung, P. S. (2019). Effect of photobiomodulation therapy on neuronal injuries by ouabain: the regulation of $\mathrm{Na}$, K-ATPase; Src; and mitogen-activated protein kinase signaling pathway. BMC Neuroscience, 20(1), 19. doi:10.1186/s12868-019-0499-3

Crossref • PubMed • PMC • Google Scholar

Sano, R., Shinozaki, Y., \& Ohta, T. (2020). Sodium-glucose cotransporters: Functional properties and pharmaceutical potential. Journal of Diabetes Investigation, 11(4), 770-782. doi:10.1111/ jdi.13255

Crossref $\bullet$ PubMed $\bullet$ PMC $\bullet$ Google Scholar

Saravia, J., Raynor, J. L., Chapman, N. M., Lim, S. A., \& Chi, H. (2020). Signaling networks in immunometabolism. Cell Research, 30(4), 328-342. doi:10.1038/s41422-020-0301-1 Crossref • PubMed • PMC • Google Scholar

Shaikh-Kader, A., Houreld, N. N., Rajendran, N. K., \& Abrahamse, H. (2021). Levels of cyclooxygenase 2, interleukin-6, and tumour necrosis factor- $\alpha$ in fibroblast cell culture models after photobiomodulation at $660 \mathrm{~nm}$. Oxidative Medicine and Cellular Longevity, 6667812. doi:10.1155/2021/6667812

Crossref • PubMed • PMC • Google Scholar

Sharma, P., Khairnar, V., Madunić, I. V., Singh, Y., Pandyra, A., Salker, M. S., Koepsell, H., Sabolić, I., Lang, F., Lang, P. A., \& Lang, K. S. (2017). SGLT1 deficiency turns listeria infection into a lethal disease in mice. CellularPhysiologyandBiochemistry,42(4), 1358-1365. doi:10.1159/000479197 Crossref $\bullet$ PubMed $\bullet$ Google Scholar

Sheccid, A. L. (2021). Photobiomodulation effects on insulin secreting beta cells (Masters dissertation). Available from DSpace Theses and Dissertations (library). URI: http://hdl.handle. net/10106/29803

Google Scholar

Shorning, B. Y., Dass, M. S., Smalley, M. J., \& Pearson, H. B. (2020). The PI3K-AKT-mTOR pathway and prostate cancer: At the crossroads of AR, MAPK, and WNT signaling. International Journal of Molecular Sciences, 21(12), 4507. doi:10.3390/ijms21124507

Crossref $\bullet$ PubMed $\bullet$ PMC $\bullet$ Google Scholar

Shyer, J. A., Flavell, R. A., \& Bailis, W. (2020). Metabolic signaling in T cells. Cell Research, 30(8), 649-659. doi:10.1038/s41422-020-0379-5

Crossref $\bullet$ PubMed $\bullet$ PMC $\bullet$ Google Scholar

Silva, G., Ferraresi, C., de Almeida, R. T., Motta, M. L., Paixão, T., Ottone, V. O., Fonseca, I. A., Oliveira, M. X., Rocha-Vieira, E., Dias-Peixoto, M. F., Esteves, E. A., Coimbra, C. C., Amorim, F. T., \& de Castro Magalhães, F. (2018). Infrared photobiomodulation (PBMT) therapy improves glucose metabolism and intracellular insulin pathway in adipose tissue of high-fat fed mice. Lasers in Medical Science, 33(3), 559-571. doi:10.1007/s10103-017-2408-2 Crossref $\bullet$ PubMed $\bullet$ Google Scholar

ISSN 1996-4536 (print) • ISSN 2311-0783 (on-line) • Біологічні Студії / Studia Biologica • 2021 • Том 15 / № 4 • C. 87-104 
Sinclair, L. V., Barthelemy, C., \& Cantrell, D. A. (2020). Single cell glucose uptake assays: A cautionary tale. Immunometabolism, 2(4), e200029. doi:10.20900/immunometab20200029 Crossref • Google Scholar

Siska, P. J. \& Rathmell, J. C. (2015). PKCs sweeten cell metabolism by phosphorylation of Glut1. Molecular Cell, 58(5), 711-2. doi:10.1016/j.molcel.2015.05.025 Crossref $\bullet$ PubMed $\bullet$ PMC $\bullet$ Google Scholar

Stabile, H., Scarno, G., Fionda, C., Gismondi, A., Santoni, A., Gadina, M., \& Sciumè, G. (2018). JAK/STAT signaling in regulation of innate lymphoid cells: The gods before the guardians. Immunological Reviews, 286(1), 148-159. doi:10.1111/imr.12705 Crossref $\bullet$ PubMed $\bullet$ PMC $\bullet$ Google Scholar

Sunemi, S. M., Teixeira, I. L. A., Mansano, B. S. D. M., de Oliveira, H. A., Antonio, E. L., de Souza Oliveira, C., Leal-Junior, E. C. P., Tucci, P. J. F., \& Serra, A. J. (2021). Post-resistance exercise photobiomodulation therapy has a more effective antioxidant effect than pre-application on muscle oxidative stress. Photochemical \& Photobiological Sciences, 20(4), 585-595. doi:10.1007/s43630-021-00042-w Crossref $\bullet$ PubMed $\bullet$ Google Scholar

Takeuchi, A., Kim, B., \& Matsuoka, S. (2020). Physiological functions of mitochondrial $\mathrm{Na}^{+}-\mathrm{Ca}^{2+}$ exchanger, NCLX, in lymphocytes. Cell Calcium, 85, 102114. doi:10.1016/j.ceca.2019.102114 Crossref $\bullet$ PubMed $\bullet$ Google Scholar

Tian, M., Qi, Y., Zhang, X., Wu, Z., Chen, J., Chen, F., Guan, W., \& Zhang, S. (2020). Regulation of the JAK2-STAT5 pathway by signaling molecules in the mammary gland. Frontiers in Cell and Developmental Biology, 8, 604896. doi:10.3389/fcell.2020.604896

Crossref $\bullet$ PubMed $\bullet$ PMC $\bullet$ Google Scholar

Vaeth, M., Maus, M., Klein-Hessling, S., Freinkman, E., Yang, J., Eckstein, M., Cameron, S., Turvey, S. E., Serfling, E., Berberich-Siebelt, F., Possemato, R., \& Feske, S. (2017). Storeoperated $\mathrm{Ca}^{2+}$ entry controls clonal expansion of $\mathrm{T}$ cells through metabolic reprogramming. Immunity, 47(4), 664-679. doi:10.1016/j.immuni.2017.09.003

Crossref $\bullet$ PubMed $\bullet$ PMC $\bullet$ Google Scholar

Walski, T., Drohomirecka, A., Bujok, J., Czerski, A., Wąż, G., Trochanowska-Pauk, N., Gorczykowski, M., Cichoń, R., \& Komorowska, M. (2018). Low-level light therapy protects red blood cells against oxidative stress and hemolysis during extracorporeal circulation. Frontiers in Physiology, 9, 647. doi:10.3389/fphys.2018.00647

Crossref $\bullet$ PubMed $\bullet$ PMC $\bullet$ Google Scholar

Wang, T., Wang, J., Hu, X., Huang, X. J., \& Chen, G. X. (2020). Current understanding of glucose transporter 4 expression and functional mechanisms. World Journal of Biological Chemistry, 11(3), 76-98. doi:10.4331/wjbc.v11.i3.76

Crossref $\bullet$ PubMed $\bullet$ PMC $\bullet$ Google Scholar

Wilson, C. S. \& Moore, D. J. (2020). B cell metabolism: An understudied opportunity to improve immune therapy in autoimmune type 1 diabetes. Immunometabolism, 2(2), e200016. doi:10.20900/immunometab20200016

Crossref $\bullet$ Google Scholar

Zhang, H., Kong, Q., Wang, J., Jiang, Y., \& Hua, H. (2020). Complex roles of cAMP-PKA-CREB signaling in cancer. Experimental Hematology \& Oncology, 9(1), 32. doi:10.1186/s40164020-00191-1

Crossref $\bullet$ PubMed $\bullet$ PMC $\bullet$ Google Scholar

Zhang, J., Wang, X., Vikash, V., Ye, Q., Wu, D., Liu, Y., \& Dong, W. (2016). ROS and ROSmediated cellular signaling. Oxidative Medicine and Cellular Longevity, 2016, 4350965. doi:10.1155/2016/4350965

Crossref • PubMed • PMC • Google Scholar

Zhang, Z., Amorosa, L. F., Petrova, A., Coyle, S., Macor, M., Nair, M., Lee, L. Y., \& Haimovich, B. (2019). TLR4 counteracts BVRA signaling in human leukocytes via differential regulation of AMPK, mTORC1 and mTORC2. Scientific Reports, 9(1), 7020. doi:10.1038/s41598-01943347-8

Crossref $\bullet$ PubMed $\bullet$ PMC $\bullet$ Google Scholar

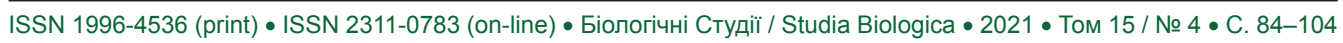


Zhang, Z., Shen, Q., Wu, X., Zhang, D., \& Xing, D. (2020). Activation of PKA/SIRT1 signaling pathway by photobiomodulation therapy reduces $A \beta$ levels in Alzheimer's disease models. Aging Cell, 19(1), e13054. doi:10.1111/acel.13054 Crossref $\bullet$ Google Scholar

Zhou, X., Li, Y., Ji, Y., Liu, T., Zhao, N., He, J., \& Yao, J. (2021). PD-1 involvement in peripheral blood CD8 ${ }^{+} \mathrm{T}$ lymphocyte dysfunction in patients with acute-on-chronic liver failure. Journal of Clinical and Translational Hepatology, 9(3), 283-290. doi:10.14218/JCTH.2020.00142 Crossref $\bullet$ PubMed $\bullet$ PMC $\bullet$ Google Scholar

Zhu, F., Wang, K. B., \& Rui, L. (2019). STAT3 activation and oncogenesis in lymphoma. Cancers (Basel), 12(1), 19. doi:10.3390/cancers12010019

Crossref • PubMed • PMC • Google Scholar

Ziegler, G. C., Almos, P., McNeill, R. V., Jansch, C., \& Lesch, K. P. (2020). Cellular effects and clinical implications of SLC2A3 copy number variation. Journal of Cellular Physiology, 235(12), 9021-9036. doi:10.1002/jcp.29753

Crossref $\bullet$ PubMed $\bullet$ Google Scholar

\section{ВПЛИВ ФОТОБІОМОДУЛЯЦІЙНОЇ ТЕРАПІЇ НА РЕГУЛЮВАННЯ ПОГЛИНАННЯ ГЛЮКОЗИ У ЛІМФОЦИТАХ ЗА ЦУКРОВОГО ДІАБЕТУ (ОГЛЯД)}

\section{А. О. Маслакова, М. Я. Люта, Н. О. Сибірна}

Львівський національний університет імені Івана Франка вул. Грушевського, 4, Львів 79005, Україна

Для більшості клітин, включаючи лімфоцити, глюкоза є основним джерелом енергії, а тому важливо зрозуміти регуляторні механізми, що контролюють роботу транспортерів глюкози. Лімфоцити - ключові клітини, які опосередковують імунну відповідь і запальні реакції. Особливістю лімфоцитів $є$ посилення утилізації глюкози за активації імунної відповіді, що сильно залежить від поглинання глюкози. Деякі дослідження демонструють, як підвищена концентрація глюкози за цукрового діабету впливає на експресію транспортерів глюкози у лімфоцитах, що корелює з порушенням імунної відповіді та може стати одним із фракторів схильності до зараження інфекційними захворюваннями. У нещодавніх дослідженнях приділяють велику увагу транспортерам глюкози як терапевтичним мішеням за умов різноманітних захворювань, включаючи цукровий діабет. У цьому огляді продемонстровано вплив фотобіомодуляційної терапії на поглинання глюкози $\mathrm{Na}^{+}$-залежним ко-транспортером глюкози SGLT1, а також полегшеною дифузією транспортерами родини GLUT (GLUT1, GLUT3, GLUT4) в лімфоцитах у нормі та за цукрового діабету.

Ключові слова: GLUT, SGLT1, фотобіомодуляція, лімфоцити, цукровий діабет 